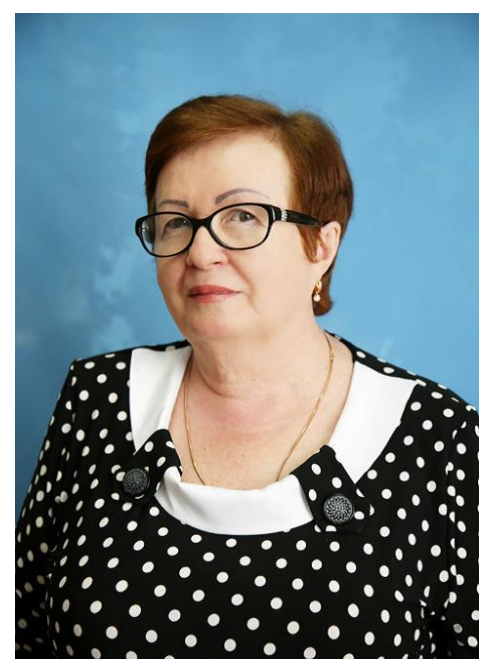

\title{
MAN AND UNIVERSE
}

\section{Simonok Valentina Petrovna,}

Doctor of Philology, Full Professor, Head of the Department of Foreign Languages № 1,

Yaroslav Mudriy National Law University, Ukraine, Kharkiv

e-mail:kafedra_i24@rambler.ru

ORCID 0000-0003-3664-9218

The knowledge of the Universe is an integral part of understanding of human nature. People can perceive themselves, their nature, essence, relations with other people only through learning and understanding the world, the laws of evolution and existence.

The concept «universe» has specific historical content, which is determined by the state and level of culture, science, technology, social relations, and nature.

The concept of «world» covers the natural and artificial environment, social relations, spiritual world of man, ways and products of spiritual creativity.

A language arms people with the tools to develop the worldview and determines the rules of her thinking and behavior. People shape their thoughts and develop the view of the world, or the whole picture of the world, through the language.

The concept «reality» is considered to be all the things that people can speak about; all classes of objects which exist and surround us or are non-existent and imaginary but still people are able to distinguish and describe them.

The lingual world-image is based on the perception, thinking, and cognition of the world with its following reflection. As the basis of cognition the reflection can be thought to be similar for people who speak different languages.

Keywords: universe; social relations; spiritual creativity; rules of thinking and behavior; picture of the world.

Introduction. According to R. Hallig, V. Vartburgh, and Yu. Karaulov, the whole Universum can be divided into three great parts: 1) Universe; 2) Man; 3) Man and Universe. Every one of the groups mentioned above in its turn can be divided into smaller parts containing different amount of units.

The fragments of the lingual world-view are different in their dynamics including the different ability to accept elements of foreign languages that is why the problem of lexical borrowing is considered in connection with their place in the Ukrainian lingual world-view.

The borrowed lexical units from the Part named «the Universe» mostly have 
nominative functions.

The characteristics of Man or the anthropologic aspect becomes especially important in the study of world-view because it makes the special human features, existence, the relations of people with the environment, and the world living conditions more expressive.

The lexical borrowings are usually connected with some parts of the Ukrainian world-view, i.e. the names of different types of social and labour activities of people.

The analysis of the borrowed lexical units shows not only the opposition of the notions 'physical - spiritual', 'natural - artificial', 'inherited - gained in the lifetime' but allows tracing the more general opposition of features reasoned by the human nature - physical, natural, social and spiritual, and special. This opposition is essential for the study of human nature, since English, French and German lexical borrowings in the Ukrainian language associated with other pairs of oppositions allow deeper understanding of the physical, psychic, and spiritual nature of people.

The integral part of the doctrine of man is the knowledge of the Universe. People can get to know themselves, their nature, essence, relations with other people only through the knowledge of the world, the laws of development and existence.

Presentation of the main body of the article. The concept of 'Universe' has the specific historical content, which is determined by the state and level of culture, science, technology, social relations, nature. According to the German philosopher M. Haydegger, «the world is the kind of human existence and penetration into the transcendental (out of the boundaries of ultimate existence) state of human existence» [1, p. 107].

If a person disappears, the world as well as the world of human existence will disappear, but this does not mean that nature and the changes that occurred in it with the help of man will disappear. The nature will only lose its qualitative clearness. The concept of 'world' covers the natural and artificial nature, social relations, the spiritual world of man, ways and products of spiritual creativity.

In this regard, the world, according to J. Trier, is also a prerequisite, and the 
final result of the division of the world, reflected absolutely identically in the minds of people speaking a given language, and in the language itself [2, p. 200].

V. Wartburg proposes a postulate that the whole picture of the world in the form in which it exists in an individual mind and in the entire lingual community, organically and without lacunas can be divided from above, from the whole to small fields, and within the fields the semantic spheres of individual words also interlock tightly [3, p. 16].

B. Worff believes that language imposes a certain world outlook on a person and determines the norms of his 7 her thinking and behavior. He built his evidence, observing the lacunae of both lingual and extra-lingual nature, identifying the language with semantics, that is, the sum of meanings [4, p. 185].

Öhman S. understanding of the question of the lingual world-view is close to that definition, 'A person forms his / her own view of the world, or the whole picture of the world, not by him / herself, but through the language. Since the difference between languages also applies to lingual content, each individual language can form a special view of the world, which can be different from the world-views created in other languages» $[5$, p. 36].

One of the issues that needs to be clarified is the meaning of the concept 'reality' that we understand it as the world that is expressed in the language.

For example, J. Lyroshet writes on this point, «When the language is said to be the system of reality representation, then there is no need to clarify that reality is not understood in ontological sense: this term is understood as everything people can speak about; all classes of objects, existing and non-existent, fictitious, which can be distinguished and imagined (in this case it refers to as «immidiate reality»); in addition, all the «objects» that can be comprehended by the mind and which can be so abstract that they cannot be imagined (in this case, it is called «mediated reality»), in this case the term «object» is used in the broad sense which means not only things, features, processes, but also intellectual and emotional qualities.All the mentioned above things taken together represent the view of the world (une représentation $\mathrm{du}$ monde), the representation of the whole reality [6, p. 177-178]. 
G. Brutyan has his own vision of the world-view: «The process of the reproduction of the world-view in human consciousness in spite of being indivisible and single construction is usually represented in the form of the sensual and rational (logical) model of reality. There is also appropriate to represent the view of the world in the form of conceptual (logical) and lingual models» [7, p. 108].

In this case G. Brutyan describes the picture of the world not from the point of view of its structure or its linguistic expression, but only from the point of view of its methodological status, because there is often an attempt to replace the picture of the world with the content of the dictionary and vice versa.

The reason for this may be, firstly, the fact that nobody can deny the relationship between the structure of the dictionary and the reality, reflected in the lexis of the language, which means that the structure of the dictionary also «reflects» something. Secondly, nobody knows how, in what form, the vocabulary functions in the head of an individual: if the words are distributed in the nests that correspond to the parts of the dictionary content; or, maybe they, according to J. Terra's metaphor, «they cover the scope of the concept like mosaic», creating the general view of the world; or it is the way of the vocabulary existence not similar to anything else.

So, this refers only to the structure of the vocabulary. Then the author continues with the estimation of the phenomenon by the native speaker discussing the question of how the vocabulary in the mind of the speaker reflects the surrounding world [8, p. 55].

R.Hallig and V.Wartburg deliberately compare the structure of the vocabulary with the «view of the world». The question for them is how the vocabulary content reflects the world-view.

Five schemes were selected, namely: Casares's, Moliner's, Mayer's, Dornzaif's and R. Hallig and W. Wartburg's.

Casares puts the concept of God on the first place, according to Yu. Karaulov, that fact reflects Casares's outlook which is associated with religious traditions. But, his idea placed on the very top does not develop, but creates a dead-end branch. Objectively, the central place by location and by nature belongs to the concept of 
Man, in the Casares's scheme, although the author himself does not speak about it. From the scheme of Casares's the following classification follows: the person who is in the center of the world of things and opposes it, divides this world into some homogeneous zones, distinguishing, for example, the living beings, devoid of reason, and on the other hand, a society of human beings, where a person is set off as an individual [9, p. 45-52].

If the special characteristic of the Casares's scheme is its anthropological orientation, then Moliner offers the «lexical cone» where the vertex is all that is significant from the standpoint of a person who feels indifferent if the object in front of him or her is a person or a stone. Both objects in his scheme represent «something».

The significant interest in the history of this question attracts the MayerDornzaif scheme, constructed logically. It reveals the common part that exists in different languages. Namely, in the Mayer - Dornsayef scheme, like Casares's, the Man is in the center of the classification.

In addition, in Mayer's classification scheme, besides the central part, there is the periphery part, whose composition is determined by the subjective moments and the means of the scheme construction (it contains the group of the most frequent grammatical words), this part is also caused by the author's outlook (if/«Religion» is in the first place in the Casares's scheme, then Dornzaif put it at the last); the specifics of the language influence the periphery part. The special features of the language manifest themselves at all levels of the hierarchical organization of the language. However, it is almost absent at the higher levels of abstraction, namely at the levels of the elements that make up the world-view.

The important issue of interest to researchers over the past two centuries is the question of the national specifics a language. In recent years, with overcoming the one-sided structuralism and returning the attention to such problems as «the people and the language», «Man and the language» in linguistics, there is a tendency to draw the balance between different aspects of language learning and returning to the problems related to the people and a person, in particular to the question of the 
national special characteristics of the language.

The national special features of the language are determined, first of all, by the internal form of a language, it can be observed at the level of words and fields. When the broad semantic zones formed by the whole complexes of fields (or fragments of the world-view) are compared, the gaps in one language are found in comparison with the other language where they are absent [10, p. 38-51].

This fact became the prerequisite for the R. Hallig and V. Wartburg's research when they were developing the principles of the classification of the lingual worldview. The proposed systematization of the lexical units absorbs the experience of a number of previous research works and is mostly perceived as universal. In R. Hallig and V. Wartburg's dictionary, the structure of the dictionary and the world-view are deliberately compared. The question for them is the extent to which the structure of the dictionary reflects the world-view.

When the ideographic dictionaries of different languages are compared, the common part in them is usually evedent.

The universal character of the main, central part in the structure of ideographic dictionaries of the Spanish, German and French languages is explained, first of all, by the unity of the material world, which is reflected in the consciousness and forms the essential basis for the world-view.

Yu. Karaulov considers the component analysis to be «one of the most widely used and most effective linguistic methods" [11, p. 11]. The purpose of such analysis is not only the distribution into components, but the search for the place and meaning.

The concept of world-view in both conceptual and in purely linguistic terms needs further elaboration.

When the representatives of ethnolinguistics, both American and European, or Neogumboldtians define the spheres where the national peculiarities of the lingual world-views reflect they base the evidence of the national specifics and differences in the reflection of the world in different languages on the fact that the main element of the special features is the word.

«The languages are distinguished not only by the way the sentences are built, 
but also how they divide the world into elements that represent the material for constructing sentences. These items are dictionary units. A 'word' is not the very known unit for their definition; a 'lexeme' and 'term' seem to be better definitions», Boris Worf wrote [4, p. 192]. These views were also supported by the German scientist G. Kandler [12, p. 264-265]. The principle of reflection lies at the heart of the linguistic view of the world. As the basis of mental processes the reflection is mostly the same in all people, regardless the language they speak.

The word itself is not a direct reflection it acts as a means of expression. It acts as the means of reflection in the field composed of words that are determined historically, socially and individually. National special features of a language are based on historical and political conditions. N. Fedorenko observes on that the national characteristics of a language are «not in the people's clothes or cuisine but in the way they understand things» $[13$, p. 160].

At the field level, the differences between languages are still very significant, but with a gradual shift to higher abstract levels such as subgroups, groups, etc., there is the tendency to reduce these differences. This is understandable because the thinking processes are the same for all people.

According to G. Melnikov, «the human psyche is a structural dynamic predictive model of external activity. The majority of the units of this model consist of concrete images - the reflections of individual denotations (phenomena and objects) a person has to deal with.

But, according to L./Vygotsky, in addition to these individual structural models the 'generalizations' are formed in the consciousness, they are independent abstract units that are structural models of classes of denotations. Thus, taking into account the virtually limitless number of individual conceptual units in the consciousness of each person, the set of abstractions sequestered by the relevant features of a certain type, all people for whom this type of characteristic is relevant, quite stable and has a fairly close composition» [14, p. 26].

According to R. Hallig, V. Wartburg, and Yu. Karaulov, the whole Universum is divided into 3 major sections: 1) the Universe; 2) Man; 3) Man and the 
Universe. Each of these sections has its own groups.

Thus, Section I the «Universe» is divided into 4 groups: 1) Sky and Celestial bodies; 2) the Earth; 3) Wildlife; 4) Plant world.

The observation of celestial phenomena belongs to the oldest human interests. Therefore, such names are rarely borrowed from other languages. Instead, the names of celestial bodies and phenomena that were discovered as the result of various scientific studies and came into the language through the scientific sources, are expressed in the Ukrainian language by the terms of other languages, some of which become general knowledge. The Anglicism квазари (the quasars), two French borrowings гало, зеніт (halo, zenith) belong to this subgroup but there are no German borrowing. This subgroup is represented by scientific narrow-terminological names.

There are some words that have double names - the old ones that originally appear in the language and newer ones that are borrowed. Thus, the ancient name мітла (a broom) was squeezed out of use by the borrowed term комета (the comet) which enters into one row with the word планета (the planet).

The Global Oceans is constantly influenced by the cosmic forces that determine the planetary process called 'tides'. It represents the periodic horizontal movements of water and fluctuations in its level. The tides are generated by the tide raising force of the Earth, the Moon and the Sun, which causes the deformation of the Earth surface and becomes noticeable in the mobile waters of the ocean.

In this subgroup there are relatively few borrowed words because there is the well-developed system of names for the water reservoirs in the Ukrainian language. Therefore, the words: океан (ocean), бухта (bay), басейн (basin), каскад (cascade), апвелінг (upwelling).

The borrowed vocabulary is presented in almost all fragments of the section «Universe», having mainly nominative function.

Section II - «Man» has the following groups: 1) Man as a living being; 2) Man as a social being; 3) Social Institutions and Relationships.

In the Section «Man», a large number of borrowings are found in the 
fragments of the world-view associated with various types of social and work activities but less borrowed units are traced in the fragments associated with its natural features of people. These fragments of the world-view have the developed system of the Ukrainian names belonging to the Proto-Slavic heritage. A few borrowings perform the expressive function: блондин, брюнет (blond, brunette), nominative-exotic: негр, мулат, квартерон (negro, mulatto, quarterone), the function of terminology-creative (the names of diseases). All these names are located on the periphery of the Ukrainian world-view.

Some of the borrowings can lose the terminological meaning and move to the colloquial style, acquiring the abusive meaning: idiom, кретин (idiot, cretin). In the political sphere of the Ukrainian world-view there are names of historical realities that perform the nominative historical function, for example: бланкіст blanquist, вандеїст vandeist, версалець versaelec, деїсm, deist, друїд druid, such names as масон (masons), (нео)нацист (neo-Nazis) and (нео)фашист (neo-fascists) are still in use nowadays.

A lot of borrowings have hyper- and hyponimic relations for example: сеньйор - васал (senior - vassal), офіиер - солдат (officer - soldier). Some names come into synonymous relationship, for example: інфант - прини (infant - prince, аудитор - ревізор (auditor - inspector). The following lexical components have function of the internationalization: губернатор (governor), департамент (department), кабінет міністрів (Cabinet of Ministers), комітет (committee), парламент (parliament), президія (presidium). The nominative-exotic function is performed by the names ерл (earl), інфант (infant), кронприни (crown prince), elector, nep (peer). The nominative and explanatory function belongs to the names of комонер (commoner), лорд-протектор (Lord Protector). The names of бакалавр (bachelor), бізнесмен (businessman), губернатор (governor), кавалер (cavalier), кредитор (creditor), магістр (master), маестро (maestro), мер (mayor) came beyond the terminology.

There are the following groups in Section III «Man and the Universe» - 1) A priori; 2) Science and Technology. Each of these groups is divided into smaller ones. 
The fragments of the lingual world-view differ in dynamics, including the different ability to absorb elements of foreign languages, because of which the problem of lexical borrowing is considered in connection with their place in the Ukrainian worldview.

L. Lisichenko, analyzing the ways of the world-view development, notes that this development takes place in two main ways. The first way is the expansion of the world-view in the process of widening the semantic space, which is inherent for the borrowings. The second one is the consolidation of the world-view, which arises in the process of deepening our knowledge of the conceptual space existing in the language [15, p. 4-5].

The first way mentioned in this study is associated with the process of borrowing of new words and with the nominative function. The second one is connected with the emergence of the synonymous values, complicated by additional semantic features, and the borrowings with stylistic means. Because of the globalization of the conceptual world-view there is a function of internationalization of certain parts of the lexical composition, which leads to the globalization of the lingual world-view.

The borrowed vocabulary is present in almost all fragments of the section «Universe» and performs predominantly nominative function. The borrowed names of the Second Section characterize a person from different points of view: physiological, psychic, social.

According to B. Serebrennikov for a native speaker of a language the real world (material and physical) exists in the form: 1) the reality itself; 2) the first signaling system (the level of sensory perception of reality);3) the third signaling (verbal) system of reality, or, according to I. Pavlov, «the purely human system of reality» $[16$, p. 35$]$.

These three levels of the perception and conception of the reality correspond to 1) the conception (household and scientific) of the general picture of the world; 2) subjective conception of the world; 3) the picture of the world objectified with through the language [17, p. 101]. 
The characteristics of a person or the anthropological aspect acquires the special value in connection with the study of the world-view, because it makes the special features of man and his / her being, the relationship between man and the world, the conditions of the existence in this world more significant. These signs are reflected in the system of names, which demonstrate all the diversity of human interaction with the environment. In this case, the main continuum of names of persons belongs to the lexical composition, which significant part consists of borrowings. As it was already noted, the borrowed vocabulary, as a rule, is connected with a certain part of the Ukrainian world-view, namely, with the names of the various types of the phenomena of social and working activity of people.

Anthropological principle in the language makes it possible to study a This category includes words that denote a person in his multilateral relations with other people, with society - «by his various institutions, all spheres of mental and practical activity of a person, of his physical, mental, ethical and moral norms» I. Simonenko 1995, p. 126]. Borrowed vocabulary makes it possible to trace not only the opposition «physical spiritual», «natural-special», «inherited-acquired during the life», but also the most generalized opposition to the signs caused by the nature of man-physical, natural, social, spiritual, special. This opposition is essential for the study of human nature, since English, French and German lexical borrowings in the Ukrainian language, associated with other pairs of oppositions, allow deeper understanding of the physical, psychic, and spiritual nature of man Part of the picture of the world «Man and the Universe» covers 2 groups: «A priori» and «Science and Technology». The group «A priori» is divided into 7 subgroups: 1) Genesis. 2) Quality and condition. 3) Relation. 4) Number and number. 5) Space and time. 6) Movement. 7) Changes. Subgroup «Being» covers both material and spiritual. Genesis is what exists: matter, things, properties, relationships, and attitudes. In the form of spiritual reality, there are ideas, theories, hypotheses, the fruits of fantasy, tales, myths, etc. Being - the general basis of practically active and cognitive development of the person of the world. An important feature of the category of being is the mandatory presence of certain things in real things certain properties. To have any properties, the 
thing first of all should first be. Major categories of being: existence, reality, reality. This subgroup includes the following borrowed names: antecedent, existentialism, individualization, quark, subsystem, substance, transcendent. The subgroup «Quality and Condition» is represented by borrowings: accidents atanassy, «entropy, collapse, parasitism, repairs.

In the objective world there is a variety of relations: social, main and nondominant, separate, individual and general, organic and inorganic, logical, and others. Everything that exists is in a relationship, and this relationship is the truth $f$ all existence. The content of the category of relationships is the interdependence of things (elements of a particular system, as well as their relative stability independence). Subgroup «Attitudes» has the following borrowing: English: antagonism, elitism; Fr.: group, class Subgroup «Number and quantity» includes the following names: English barrel, bushel, gallon, inch, dozen, mile, pint, foot, centimeters, yard; fr.: gram quadrillion, kilogram, curie, kilometer, liter, meter, million, billion, centimeter, ton, trillion; Gem: Gross, Centner, Corner, Shtish The concept of «space» and «time» the most ancient concepts of human culture They are at the core of the cosmological problem - the question of the universe, its origin, its finiteness or infinity. In modern science, the physical theory of space and time the theory of relativity, created by A. Einstein. It is also called the substantive concept of space and time. This category has three dimensions: length, width and height. Subgroup «Space» is limited to the following borrowings: English: Quasars, Continent; Fr.: atmosphere, color, nativeism, planet, pulsar, relief, territory, center; gm: occident Time is the absolute duration flowing independently of events in the world and in the universe with its own original and unchanging rhythm. It is characterized by durability and irreversibility. The subgroup «Time» has only French borrowings: interval, milenium, moment, period, Renaissance, cycle; Ital: Quattrocento (the era of the Early Renaissance) In the world there is always a movement: all things are moving, their properties and attitudes change, there is a continuous process of modification, transformation, vibrations between being and non-existence. Each star is a peculiar sun, around which the planets move. Together 
with other stars and their companions, they participate in the rotation of the Galaxy around its axis. The galaxy in turn moves relative to other galaxies. The universe is in a continuous motion to its new statuses. In every living system there are constantly internal processes associated with the pulsation of energy, information, consumption, processing and assimilation. Social systems exist through the exchange of information, human activities, the interaction of various components of the social organism. The motor is inherent in the cause and effect category. Subgroup «Movement» is represented by borrowings: dynamics, evolution. Subgroup «Changes» covers such borrowings: vegetation, generation, erosion, lethality, mutation The group «A priori» in the ISS-is associated with the nomination of concepts and phenomena that exist independently of a person. If in the class «Man» were presented the words arising directly from the relationship between man and the environment, where he is not only an observer and a researcher, but also an active participant in the creation of this world and himself (society, life, all spheres of human life, all manifestations her activities, etc.), then the class «A priori» includes words that denote the redefined by a person numerical quantitative phenomena that exist independently of its experience. The term «A priori» in this case is used conventionally, because in philosophy it is known to denote the knowledge that preceded the experience and is independent of it. In works devoted to questions about the linguistic picture of the world, this term coexists to denote not specific types of knowledge, and the linguistic consequences of knowledge of phenomena that do not depend on a person. In the section «Man and the Universe predominates the names of abstract concepts. Although the words of this section serve phenomena known to man from ancient times and belong to the oldest layer however, in this part of the picture of the world, foreign elements are penetrated, in particular, to designate the quantity in connection with the existence of various measures (barrel, gallon, gram, gross, curie, pound). Borrowed are separate spatial names (zenith, colour, continent, planet); time (milenium, Renaissance), changes (vegetation, erosion, mutation). As can be seen from the analyzed material, the lexical borrowings of the «A priori» unit are not numerous, they belong mainly to the sphere of scientific communication. For 
example, the term atanassia means immortality, entropy (transformation) is part of the internal energy of a closed system of the universe that can not be converted into mechanical work, the individual is the distribution of the general to the individual, the pulsar is a blac hole in space. The second group of the chapter «Man and the Universe» is called «Science and Technology». However, in this case the unity of classification is violated because «Engineering» covers a large number of phenomena and artifacts that are related to the immediate activity of a person and arise from her experience. Therefore, only the names of scientific concepts that are learned through experience, and not through creation, should be included in this group. Since entific activity is largely of an international character, it is influenced by international terms in the picture of the world, which is why it contains a large number of borrowings, including Romanesque and Germanic languages. XXI century characterize the technical, atomic, space, cybernetic age of automation, computerization, robotics, etc., associated with the problem of assessing the phenomenon of technology in the development of modern civilization. An optimistic assessment protects the development of technology as a prerequisite for the gradual harmonization of life in society. The progress of technology allows you to overcome the fatal diseases, resolve the conflict situations in society, and provide a dynamic state of public infrastructure. The pessimistic evaluation is called technophobia - horror in technology. Proponents of such an assessment believe that technical development will turn the person into an element of technical devices. Computer equipment will not make a person smarter, but rather even more valnerable and helpless. The planet Earth will gradualy become unfit for life, and, consequently, the human desire to achieve well-being by means of technology will lead to its degeneration. Proponents of a neutral assessment believe that everything depends on what the person will do with the technique Any classification is to a certain extent conditional. This also applies to the classification scheme of the world picture. The group «Science and Technology» should include a significant number of borrowed words belonging to the bioindustry (cloning, genetic engineering); space, electronic technology (bit, interface, CDs, laser printer, megabytes, monitor, multimedia, pixel, sweat, file); 
nuclear physics; transport; telecommunications Much of the words denoting scientific concepts are open to inference and are not given to a person in direct erception. In this subgroup there is a large number of borrowed words, but much $f$ them come from ancient languages or created on their basis, so for the livin European remained less spac The division of the language universe into separate constituents controversial and imperfect, which means that the words of one circle of functioning often fall into different parts of the world's linguistic picture or ane united in one part, although they differ in essential features. The analyzed subgroup is characterized by the presence of certain terminology. Terminological units are noted not only as a correlation with a certain reality, but also depend on the place in the terminology system. Part of the terminology vocabulary is located on the periphery of the linguistic picture of the world, creating a certain layer, which constantly interacts with the nuclear part. So, with the development of computer technology, terminology gradually moved from the periphery to the nucleus. These words fulfill the nominative-terminological function. Terms can penetrate into the bulk of the linguistic image, not only the nominative value, but also the derivative. The terminology of each science is a sign system. In contrast to the long-borrowed vocabulary, which organically intertwines with the language system and interacts with it, terminology is established largely arbitrarily by representatives of a science. Since the linguistic picture of the world is heterogeneous in the composition of words, concepts and phenomena that are heterogeneous in relation to the time of occurrence of certain phenomena in the conceptual picture and, respectively, the time of their nomination, borrowing is presented in different parts of the linguistic picture of the world: the most receptive are those parts of the linguistic picture of the world characterizing a person. These are the names of supporters of political parties, movements, religious-philosophical currents, and scientific directions.

These borrowings carry out various functions: nominative-historical, nominative- planatory, nominative-exotic and function of the internationalization of lexical composition. Numerous borrowings characterizing a person by nature, carry an expressive, nominative-exotic function and a function of term derivation. They are 
$\mathrm{n}$ the periphery of the Ukrainian linguistic picture of the world. Some titles went beyond narrow terminology and belong to the colloquial style. For borrowing this section is characterized by hyper-hyponymic and synonymous relations. Less than borrowed words are presented in parts of the universe «Plant and animal world This is due to the fact that plants and animals endemic for Ukraine and the Slavic world have mainly long-standing proper Ukrainian names (birch, maple, aspen) The words, which refer to the fauna and flora of other regions of the world, in the Ukrainian language belong to either the scientific style or perform the stylistic function as exoticism, for example: bison, hyena, doman, sperm whale hummingbird, nepentes, panda, sarachenia. As a result of contact between ethnic groups and the exchange of experience, the conceptual picture of the world in the Ukrainian ethnic consciousness is being developed, which requires an appropriate expansion (increase in number) or deepening (semantic content) of words, including through borrowing. The Hss consequence of these processes is the gradual alignment and unification of the of different languages, especially in the part related to the progress in science and technology in the last several centuries. Thus, in the Ukrainian linguistic picture of the world borrowing occupy an important place as a means of expressing universal concepts and phenomena. They do not constitute a separate subsystem, but are components of all fragments of the language universe. The borrowed words can not feel for a long time the alien body the language picture of the world of the recipient language. Since borrowing is the name of a certain fragment of the linguistic picture of the world, they seek their place in it and adapt or the linguistic system pushes them to the periphery Thesaurus interpretation suggests that the system fragments of the linguistic picture of the world, although having a certain stable structure, are characterized not by seclusion but by openness, the possibility of its replenishment, including borrowed words.

\section{Список літератури}

1. Хайдеггер М. Время картины мира. Новая технократическая волна. 1992. С. 107108.

2. Trier J. Deutsche Bedeutung sforschung. Germanische Philologie. Ergebnisse und Aufgaben. Festschift für O. Behaghel. Heidelberg, 1934. S. 188-225.

3. Wartburg W. con. Einführung in Problematik und Methodik der Sprachwissenschaft. 
Tübingen, $1962.165 \mathrm{p}$. $183-198$.

4. Уорф Б. Л. Лингвистика и логика. Новое в лингвистике. Вып. 1. Москва, 1960. С.

5. Öhman S. Wortinhalt und Weltbild. Vergleichende und methodologische Studien zu Bedeutungslechre und Wortfeldtheorie. Stockholm, 1951. P. 36-51.

6. Larochette J. La représentation de la réalité. Folia linguistica. Vol. VI. 1973. № 12. P. $177-178$.

7. Брутян Г. А. Язык и картина мира. Философские науки. 1973. № 1. С. 108-109.

8. Hallig R. Begrieffssystem als Grundlage für die Lexikographie. Berlin, 1963. 291 p.

9. Караулов Ю. Н. Общая и русская идеография. Москва : Наука, 1976. 354 с.

10. Степанов Г. В. Современные языковые союзы. Типология сходств и различий в группе близкородственных языков. Кишинев, 1972. С. 38-51.

11. Караулов Ю. Н. Лингвистическое конструирование и тезаурус литературного языка. Москва : Наука, 1981. 328 с.

12. Kandler G. Die Lücke im Spachlichen Welbilt. Sprache - Schlüssel zur Welt. Festschrift für L. Weisgerber. Düsseldorf, 1959. S. 264-265.

13. Федоренко Н. Кавабата: взгляд в прекрасное. Иностранная литература. 1974. № 7. C. $160-165$.

14. Мельников Г. П. Типы означаемых языкового знака и детерминанта. Проблемы семантики. Москва : Наука, 1974. 383 с.

15. Лисиченко Л. А. Концептуальная и языковая картины мира и их взаимодействие. Семантика и прагматика языковых единии : сб. науч. трудов. Харьков : ХГПИ им. Г. С. Сковороды, 1991. С. 3-9.

16. Павлов И. П. Полное собрание сочинений. Т. 3. Кн. 2. Изд. 2-е. Москва-Ленинград : AH CCCP, 1951. $439 \mathrm{c}$.

17. Серебренников Б. А. Роль человеческого фактора в языке. Язык и мышление. Москва : Наука, 1988. 244 с.

\section{References}

1. Hajdegger, M. (1992). Vremja kartiny mira. Novaja tehnokraticheskaja volna, 107-108 [in Russian].

2. Trier, J. (1934). Deutsche Bedeutung sforschung. Germanische Philologie. Ergebnisse und Aufgaben. Festschift für O. Behaghel. Heidelberg, 188-225.

3. Wartburg, W. con. (1962). Einführung in Problematik und Methodik der Sprachwissenschaft. Tübingen. Russian].

4. Uorf, B.L. (1960). Lingvistika i logika. Novoe v lingvistike, issue 1. Moscow, 183-198 [in

5. Öhman, S. (1951). Wortinhalt und Weltbild. Vergleichende und methodologische Studien zu Bedeutungslechre und Wortfeldtheorie. Stockholm, 36-51. $177-178$.

6. Larochette, J. (1973). La représentation de la réalité. Folia linguistica. Vol. VI. No 12.

7. Brutjan G.A. (1973). Jazyk i kartina mira. Filosofskie nauki, 1, 108-109.

8. Hallig, R. (1963). Begrieffssystem als Grundlage für die Lexikographie. Berlin.

9. Karaulov, Ju.N. (1976). Obshhaja i russkaja ideografija. Moscow: Nauka [in Russian].

10. Stepanov, G.V. (1972). Sovremennye jazykovye sojuzy. Tipologija shodstv i razlichij v gruppe blizkorodstvennyh jazykov. Kishinev, 38-51 [in Russian].

11. Karaulov, Ju.N. (1981). Lingvisticheskoe konstruirovanie i tezaurus literaturnogo jazyka. Moscow: Nauka [in Russian].

12. Kandler, G. (1959). Die Lücke im Spachlichen Welbilt. Sprache - Schlüssel zur Welt. Festschrift für L. Weisgerber. Düsseldorf, 264-265.

13. Fedorenko, N. (1974). Kavabata: vzgljad v prekrasnoe. Inostrannaja literature, 7, 160165 [in Russian]. 
14. Melnikov, G.P. (1974). Tipy oznachaemyh jazykovogo znaka i determinanta. Problemy semantiki. Moscow: Nauka [in Russian]

15. Lisichenko, L.A. (1991). Konceptual'naja i jazykovaja kartiny mira i ih vzaimodejstvie. Semantika i pragmatika jazykovyh edinic. Kharkov: HGPI im. G. S. Skovorody, 3-9 [in Russian]

16. Pavlov, I.P. (1951). Polnoe sobranie sochinenij. Vol. 3. Book 2. Moscow - Leningrad: AN SSSR [in Russian].

17. Serebrennikov, B.A. (1988). Rol chelovecheskogo faktora v jazyke. Jazyk i myshlenie. Moscow : Nauka [in Russian].

Симонок В. П., д-р філол. наук, проф., завідувач кафедри іноземних мов № 1, Національний юридичний університет імені Ярослава Мудрого, Україна, м. Харків.

e-mail: kafedra_i24@ rambler.ru ; ORCID 0000-0003-3664-9218

\section{Людина і Всесвіт}

Складовою частиною вчення про людину є знання про Всесвіт. Людина може пізнати саму себе, свою природу, сутність, відносини з іниили людьли тільки через пізнання світу, законів розвитку та існування. Поняття «всесвіт» має конкретно-історичний зміст, щуо визначається станом і рівнем культури, науки, техніки, суспільних відносин, природи.

Поняття «світ» охоплює натуральну $i$ штучну природу, сочіальні відносини, духовний світ людини, способи і продукти духовної творчості. Мова нав язує людині певний світогляд $і$ зумовлює норми ії мислення і поведінки.

Людина формує свій погляд на світ або всю картину світу не сама, а за посередництвом мови. Під реальністю розуміється все те, про що людина може висловити; всі класи об'єктів, існуючі та неіснуючі, фіктивні, які вона здатна розрізняти та які може уявити собі.

В основі мовної картини світу лежить принщип відображення. Як база мисленнєвих процесів відображення принципово однакове в усіх людей, незалежно від того, носіями якой мови вони є. Розвиток мовної картини світу (МКС) відбувається двома основними способами. Перший полягає в розширенні МКС у прочесі освоєння нового семантичного простору, що властивий $i$ запозиченням. Другий - ущільнення МКС, щзо виникає в прочесі поглиблення наших знань про вже освосний мовою конщептуальний простір. Перший шлях пов'язаний з появою нових запозичених слів та з номінативною функиією. Другий - із виникненням синонімічних значень, ускладнених додатковими семантичними ознаками, $i$ запозичень стильового та стилістичного засобу. У зв'язку з глобалізачією концептуальної картини світу з'являсться функиія інтернаціоналізації певних ланок лексичного складу, щяо призводить до глобалізації мовної картини світу. Слово ж безпосередньо не є власне відображенням, воно виступає засобом висловлювання. Засобом відображення воно виступає в полі, яке складається зі слів і має історичну, сочіальну та індивідуальну зумовленість. Історико-політична зумовленість поля - це те, щзо зветься національною специифікою.

Ключові слова: Всесвіт; соціальні відносини; духовна творчість; правила мислення і поведінки; картина світу.

Симонок В. П., доктор филологических наук, професор, заведующая кафедры иностранных языков № 1, Национальний юридический университет имени Ярослава Мудрого, Украина, г. Харьков.

e-mail: kafedra_i24@rambler.ru ; ORCID 0000-0003-3664-9218

\section{Человек и Вселенная}

Составной частью учения о человеке является знание о Вселенной. Человек может познать самого себя, свою природу, сущность, отномения с другими людьми только через 
познание мира, законов развития и существования. Понятие «вселенная» имеет конкретноисторический смысл, определяется состоянием и уровнем культуры, науки, техники, общественных отношений, природы.

Понятие «мир» охватывает натуральную и искусственную природу, социальные отночения, духовный мир человека, способы и продукты духовного творчества. Язык навязывает человеку определенное мировоззрение $u$ приводит нормы его мышления $u$ поведения.

Человек формирует свой взгляд на мир или всю картину мира не одна, а через посредство языка. Под реальностью понимается все то, что человек может выразить; все классы объектов, существующие и несуществующие, фиктивные, которые он способен различать и представить себе.

В основе языковой картины мира лежит принщип отражения. В качестве базы мыслительных процессов отображение принциииально одинаково у всех людей, независимо от того, являются ли они носителями языка. Развитие языковой картины мира (ЯКМ) происходит двумя основными способами. Первый заключается в расширении ЯКМ в процессе освоения нового семантического пространства, присущий и заимствованию. Второй - уплотнение ЯКМ, возникает в проиессе углубления наших знаний об уже освоен языке концептуальное пространство. Первый путь связан с появлением новых заимствованных слов и с номинативной функиией. Второй - с возникновением синонимических значений, осложненных дополнительными семантическими признаками, $u$ заимствований стилевого и стилистического средства. $B$ связи $с$ глобализацией концептуальной картины мира появляется функиия интернационализации определенных звеньев лексического состава, что приводит к глобализации языковой картины мира. Слово же непосредственно не является собственно отражением, оно выступает средством выражения. Средством отображения оно выступает в поле, состоящее из слов и имеет историческую, сочииальную и индивидуальную обусловленность. Историко-политическая обусловленность поля - это то, что называется начиональной спецификой.

Ключевые слова: Вселенная; социальные отношения; духовное творчество; правила мышления и поведения; картина мира.

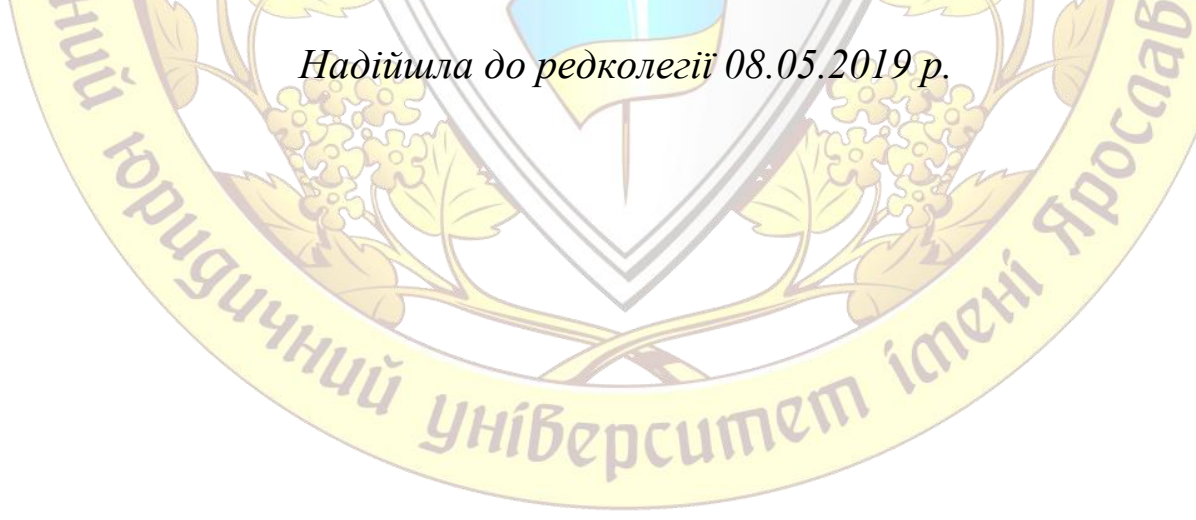

